Article

\title{
Sexual Violence, Race and Media (In)Visibility: Intersectional Complexities in a Transnational Frame
}

\section{Vrushali Patil ${ }^{1, \dagger, *}$ and Bandana Purkayastha ${ }^{2, \dagger}$}

1 Department of Global \& Sociocultural Studies, Florida International University, 11200 SW 8th St, DM 212 Miami, FL 33199, USA

2 Department of Sociology, University of Connecticut, University of Connecticut Unit 1068, 344 Mansfield Road, Storrs, CT 06269, USA; E-Mail: bandana.purkayastha@uconn.edu

$\dagger$ These authors contributed equally to this work.

* Author to whom correspondence should be addressed; E-Mail: patilv@fiu.edu; Tel.: +1-305-348-0519.

Academic Editor: Katrina Bell McDonald

Received: 26 May 2015 / Accepted: 28 July 2015 / Published: 10 August 2015

\begin{abstract}
Intersectional scholarship argues that women of color have distinct experiences of rape compared to white women and highlights their relative invisibility as victims compared to white women victims in news media. While the bulk of intersectional work has examined such issues within one nation and particularly within the US, in an era of increasingly transnationalized media content, we explore such intersectionalities in a transnational frame. That is, we explore the treatment of the rape of a local Indian woman in New Delhi, India, and the rape of a white woman in Steubenville, USA, in the New York Times and the Times of India. We find that contra assumptions in the intersectional literature, the racialized Indian victim is hyper-visible across both papers while the white US victim is relatively invisible. Situating both newspapers within the global histories of the development of news as a particular genre of storytelling, we argue that their respective locations within larger processes shaped by colonial, imperial and neo-colonial histories have critical implications for the coverage each paper offers. Thus, we argue that issues of race and visibility in media operate very differently depending on the space and scale of analysis. In an increasingly globalized world, then, we must start paying attention to the transnational and its implications for rape, race and (in)visibility in news media. Ultimately, our approach brings together processes of racialization at multiple scales - both below the nation and above the nation - to offer a more complex, multi-scalar understanding of how
\end{abstract}


racialization processes impact rape coverage.

Keywords: news media; intersectionality; rape; US; India; transnationalism

\section{Introduction}

Rape has been a central feature of intersectional analysis and critique since Kimberle Crenshaw coined the term in her seminal 1989 essay, "Demarginalizing the Intersection..." In this piece, Crenshaw outlined how, in opposition to the mainstream feminist treatment of rape as primarily the manifestation of male power over female sexuality, for black women "sexist expectations of chastity and racist assumptions of sexual promiscuity combined to create a distinct set of issues" [1] (p. 159). In "Mapping the Margins..." Crenshaw further discussed the marginalization of black women in anti-rape discourses and argued that "women of color rape victims tend to be ignored in media" [2] (p. 1268). A considerable literature on race, sexual assault and media since then has generally confirmed Crenshaw's findings, such that the invisibility of black and other minority women compared to white women as victims of sexual assault in the media has become a truism in the literature. In this paper, we extend this concern regarding media, race and rape to recent cases of sexual assault in the media. In particular, we explore two rapes that emerged in the US media toward the end of 2012 - the rape of a white college student at a party in Steubenville, $\mathrm{OH}$ and the rape of a local psychotherapy student aboard a bus in New Delhi, India. In contrast to the bulk of intersectional work on this matter which has examined issues of media representation within one nation and particularly within the US, we examine such questions in an era of increasingly transnationalized media content (not to mention media distribution and consumption). We compare coverage of both cases in two "world" newspapers [3-5] - The New York Times (NYT) and the Times of India (TOI). We find that contra assumptions in the intersectional literature, the woman of color victim in the Delhi rape case is hyper-visible across both papers while the white Steubenville victim is relatively invisible. We situate both newspapers within the global histories of the development of news as a particular genre of storytelling. We argue that their respective locations within larger processes shaped by colonial, imperial and neo-colonial histories have critical implications for the coverage each paper offers. While operating differently for each paper, for both papers these broader logics are central to understanding the greater coverage of and focus on the Delhi case, as well as the relative neglect of the Steubenville case; moreover, such differences are also fundamental for understanding the variation in terms of content of the coverage provided by each paper. Thus we argue that issues of race and visibility in media operate very differently depending on the space and scale of analysis. While intersectional work has typically focused on such questions at the scale of the nation and in terms of space, particularly one nation - The US - patterns of representation and visibility at this US-national scale do not necessarily hold at the transnational scale or in other places. In an increasingly globalized world, then, we must start paying attention to the transnational and its implications for rape, race and (in)visibility in news media. Such an approach shows how differentially racialized groups such as particular groups of women of color within the US or Orientalized women in South Asia may be impacted very differently within these processes. Ultimately, our approach brings together processes of racialization at multiple 
scales - both below the nation and above the nation-to offer a more complex, multi-scalar understanding of how racialization processes impact rape coverage.

In what follows, we begin with an overview of feminist and especially intersectional approaches to rape in the media, arguing that this work has typically focused on national news within the US and neglected global or international news. We then outline the history and development of global news, highlighting how its development in the context of North-South power relations and nationalism has shaped this news, including news coverage of rape. We then examine coverage of each newspaper from the date of each event (11 August 2012 for the Steubenville case and 16 December 2012 for the New Delhi case) through 16 March 2013, ${ }^{1}$ and ask the following questions: how many stories are published for each case, and how do the coverage, analysis and opinions offered in the two publications for each case compare? Are the papers differentially oriented toward each case? Furthermore for each paper, does the national location of the rape case matter and if so, how? Finally, how do historical and contemporary cross-border processes shape how each case is constructed in each space? We end with a discussion of our findings and implications for transnationalizing intersectional analyses of rape, race and media.

\section{Feminist and Intersectional Approaches to News Coverage of Rape}

As Gaye Tuchman wrote over forty years ago, news socially constructs reality [6]. Thus the news media have a tremendous power in shaping and reproducing as well as contesting norms having to do with gender and sexuality. Of course one central way in which power operates in news media is in terms of coverage and visibility. That is, what is covered gains an aura of legitimacy over what is not, as that which deserves public attention and is noteworthy. Such visibility or relative emphasis in news "creates a hierarchy of moral salience" [7] (pp. 23-34). Regarding rape in particular, mainstream media coverage is said to be shaped by a series of "rape myths" [8]. These are a core set of assumptions which distinguish "real" or "ideal" rape from "not real" rape: that "real" rape occurs in a non-domestic setting typically at night, in which the rapist is a monstrous (male) stranger who attacks a (female) victim with a weapon, where the victim's appearance, dress and behavior are unimpeachable, and where the victim physically resists and sustains visible injuries. The closer a rape comes to this ideal, the more likely that it will be recognized as "real" rape and the offender will get the blame, while the further away it is, the more likely that it will not be recognized as real rape and the victim will get the blame [8-11]. Thus, such rape myths serve to neglect marital and acquaintance rape and fail to recognize the mundane and interpersonal settings within which rape typically occurs. (Obviously such rape myths also neglect same-sex rape, as well as rape that occurs in institutional settings such as prisons and the military.

Indeed, Burt argues that in most cases, perpetrators are known to the victim, no weapon is involved, and there is no visible physical injury beyond mild bruises [8]. Wilson et al. also add that rather than

1 While we initially sought to examine the coverage of each rape for a period of three months after each event, this was not possible because there is no coverage of the Steubenville rape case, dated 11 August 2012 until 16 December 2012. Thus we decided to make our cut off point three months after the Delhi gang rape (dated 16 December 2012) in order to have cases to compare. 
being "monsters", rapists also tend to have a more "normal" psychological profile than any other kind of criminal [9] (p. 14).

Beginning particularly in the late eighties, intersectional critiques further highlighted the race, class and other power relations beyond those of gender which shape dominant notions of rape, victimhood and perpetrators in media and society at large. By intersectionality we specifically mean the nation-focused literature that has examined the multiple axes of power within the country that make marginalized and racial minority women's rape invisible. Critical transnational scholarship has also examined intersecting power hierarchies and the imageries and texts that have sustained these power hierarchies [12-19]. However, while the latter (particularly the feminist work within this transnational literature) build on fundamental intersectional insights and extend them to the transnational scale, feminist transnational insights about power hierarchies across countries have not consistently influenced the nation-focused scholarship on intersectionality (For more on tensions between these approaches, see [20-23]). Situated within critical transnational scholarship, then, we direct our discussion here to the nation-focused scholarship on intersectionality. By bringing intersectional insights to cross-border processes, we demonstrate how the sub/national and the trans/national actually work together to perpetuate gendered racialization in news media today.

From the beginning, intersectional interventions complicated the mainstream feminist focus on gendered power relations within rape myths to highlight key racial, class and other dimensions of these myths. These dimensions include, for example, the notion that white men, especially prosperous, educated and/or handsome ones, do not commit such crimes; that violence against white women by men of color is bad; and that violence against women of color by white men is not crime [24] (p. 81). In terms of victims, while most cases of gender violence are not covered at all, female victims that are young, or old and frail, or rich, white, and privileged are more likely to lead to coverage [24] (pp. 81-82). In terms of perpetrators, Wilson et al. write that legitimate victimhood status also tends to be ascribed more when the perpetrators are lower class men or men of color [9] (p. 214). This is because "members of the lower-classes, including people of color (who are usually assumed to be lower class even if they are not), are constructed as both naturally more prone to perpetrating violence and as less legitimate victims... Specifically, men of color are usually portrayed as natural perpetrators and women of color as 'un-rape-able' because of dominant racist stenotypes regarding the animalistic nature and sexual promiscuity of blacks" [25] (p. 49) and parallel images of other people of color [26,27]. On the other hand, offenders get less blame when they come from higher class backgrounds than their victims or are white [11] (pp. 16-17). ${ }^{2}$ Indeed, as Moorti writes in a study of television news,

the news in the United States is enunciated from a white [male], normative standpoint ....When the rape coverage is concerned with nonwhite participants, the news tends to foreground race-based assumptions of sexuality... where black masculinity is demonized. Indeed, racial difference becomes the primary explanatory framework for the crime. When the coverage is concerned with white participants, the news foregrounds gender-based assumptions of sexuality [28] (pp. 71-73).

2 Interestingly, Valerie Smith found that in contrast to such tendencies in the dominant media, the black press can do the opposite and focus on the racialization of rape while discounting the crime itself. 
The racialized dimensions of news coverage mean that while most rapes actually occur within a particular "racial" group (and within a particular class), the rape of a white woman by a black man is the most commonly covered type of rape, while the rape of a black woman by a black man is the least covered type of rape [9] (p. 214).

A central point that is reiterated in intersectional scholarship, then, is the argument that women of color are invisible as rape victims in the news media compared to white women [2,9,24,25,29,30]. However, as legitimate as such an argument seems to be for the US generally, it leaves us at a loss to explain the particular visibility of the Delhi case within the US media. Certainly, the Delhi case aligns more closely with problematic notions of "real rape" than does the Steubenville case. Hence while the Steubenville case is a classic example of the sort of acquaintance rape not taken seriously in media, the Delhi case involves a number of key "requirements", including perpetrators unbeknownst to the victim; occurrence in a public setting; no drinking involved, particularly on the part of the victim; and racialized perpetrators. We argue, however, that the transnational is a key dimension of this visibility, something that intersectional work on this issue has typically neglected. From this perspective, the 2009 edited volume by Cuklanz and Moorti makes some fundamental contributions. That is, this volume moves beyond the US to look at the "complex cartographies of oppression [in the Global South] that cannot be reduced to the sex binary... [as well as the] particular ways in which 'gender and violence' must be situated within a historical context, specifically the complicated and interconnected histories of western colonialisms and global capitalism" [31] (pp. 3-10). The volume has a number of pieces on media treatments of rape and sexual assault outside of the US, including in Pakistan [32], in Okinawa [33], and in South Africa [34]. While the piece on Pakistan examines local media, the other two examine both local and extra-local media. And yet, none these discuss tensions between local and extra-local media or how a particular case of sexual assault may be treated differently in media whose primary audiences are in different countries. Hence, none of these pieces are able to explore how a rape incident in one country might be covered in another and the intersectional complexities that might shape such border crossings. In this paper, then, this is precisely our goal. We begin first with a short overview of the colonial, postcolonial and nationalist politics of news media.

\subsection{Situating News Media: Colonial, Postcolonial and Nationalist Dimensions}

Scholars have highlighted that journalism as a particular set of discourses and practices, along with its associated formats, genres, institutions and organizations, including professional news organizations and the news agencies which create news reports and sell them to various news organizations, has its origins in the Global North [35-37]. Developing especially in the heyday of nationalism in Europe and the US, moreover, news media played a significant role in the consolidation of national boundaries there. Silverstone points out that "they enabled the fixing and spreading of vernacular languages and, through that emergence, the boundaries and identities of the embryonic modern nation-state" [38] (p. 19) in the west. One long term consequence in terms of content, then, is that "news is principally about the nation, with most news across countries focusing primarily on the domestic arena [39] (pp. 19-31). In this vein, Gans" study of the news media in the US in the seventies makes the case that foreign news tends to be reported only for countries of national interest, with other countries covered only when there are "unusually dramatic happenings" [39] (p. 31). 
Through this primary focus on the nation, then, the media construct the moral order of the nation [38]. Like other cultural texts, media discourses "legitimate a given distribution of power, both within and beyond the borders of the nation" [16] (p. 7). Journalists manage, along with others, "the symbolic arena, the public stage on which national, societal and other messages are made available to everyone who can become an audience member. They highlight stories of moral order and disorder, which "frame the news as morality plays". As Klein has discussed about cultural texts, journalists are involved in "the creative use of language and deployment of shared stories" [16] (p. 6). In this way, they act "as a kind of Greek chorus for nation and society" and guard the moral order. This sort of moral disorder news therefore reinforces and re-legitimates dominant national and societal values by publicizing and helping to punish those who deviate from the values" [39] (pp. 293-298). In these tales, news tends to emphasize melodrama, turning complex processes into morality tales of battle between antagonists, often between good guys and bad guys, with clearly identified individuals standing in for large and more difficult-to-grasp social forces [7] (p. 42).

Furthermore, the globalization of news beyond these western and nationalist origins has been critically shaped by North-South power relations. For example, Machin highlights that central to the global spread of news in terms of content (and also as a genre) has been the news agency. News agencies started in the middle of the 1800 s to supply newspapers with news items from across the world. They first started in Germany, France, and the UK. While national news agencies also emerged, the three major agencies managed to monopolize the flow of news and "form a cartel that divided up the world in the same way as empire-building nation states in that same period divided up the world to form their colonial empires" [37] (pp. 1-2). In the 1930s, the "cartel" of European news agencies collapsed but the dominance of Europe was only replaced by the dominance of the US. ${ }^{3}$ Not surprisingly, then, many news agency subscribers in Southern spaces have been troubled by the mostly negative news about them; and in the sixties, some newly independent African countries set up their own news agencies [37,40].

The "geographic inequality" represented by these Northern-dominated global news agencies is further buoyed by a number of other interrelated structural factors. For example the location or home base of major media companies today tends to be in G-7 countries, which as some of the wealthiest and most powerful countries in the world, comprise the heart of the Global North. Thus most global media organizations are primarily geared to the interests and views of audiences in these countries. The unevenness of global news coverage is further shaped by where news organizations locate their foreign correspondents, with these tending to be split about evenly among North America, Western Europe, and the rest of the world. Finally, regarding the nationalist feature of news, regardless of how international a news organization purports to be, it's primary audience tends to be within one country. For example, although the NYT is one of the most international news organizations in the world, with more foreign news bureaus than perhaps any other news organization, it still primarily targets the home audience of the US [41]. What this means in terms of foreign content is that news organizations domesticate extra-national events in terms that will make sense for their national markets [40].

3 Mody points to one study that thus found even in the 1980s, the news agency of each area's former colonizer dominated the inputs and outputs of news for that region. 
The geographic inequality and nationalist dimensions of global news thus have deep historical rootsand continue to have far-reaching consequences. In the seventies, such tensions came to a head in UNESCO, where representatives of newly independent countries sought a "New World Information and Communication Order". Northern countries such as the US, UK and Netherlands balked at such discussions, however, and withdrew from UNESCO for almost twenty years [40].

In recent years, however, some scholars have pointed to the rise of Asia as formative of a shift in some of these patterns. Numerically, eight of the world's top ten paid for daily papers are produced in Asia, and the largest national newspaper markets are China, Japan, and India [40,41]. Indeed, Thussu argues that the recent rise of China and India are interrupting historical European and US-dominated processes and having significant impact on global media content and media flows [42].

What are the implications of these global histories for news around the world today? Some scholars argue that there are "remarkable similarities" in "what is defined as news across cultures", as the globalization of news as a particular genre of discourse has had critical consequences for news values [36]. And yet, given the North-South tensions elaborated above, it is also important to note differences. In her work on news dailies in India in the eighties for example, [43] argued that being of the Global South implies a fundamentally different role on the part of the national news media. In particular, she identified a distinct "Indian perspective" across different dailies which cut across differences in readership, language and region wherein there was much more of an emphasis on assisting the postcolonial government in the task of nation-building, distinct categories of news such as development news, and a greater balance of positive stories compared to the US media. More recently, however, others have pointed to a shift since liberalization, with news media now much more oriented to the market. Indeed, in India this shift was led in particular by the TOI, which in the eighties started to target the individual urban, middle class reader as consumer with news that would provide this consumer with use value and that was more "youthful" and "optimistic" [44]. However, Mody's fascinating study supports the idea that there are important distinctions: in her work on the treatment of the Darfur crisis in ten papers across the world, she finds that the major predictor of how a paper covered the event is current national interest. While this may be in conformity with the idea that there are "remarkable similarities" in what is defined as news values, Northern and Southern states can have quite distinct national interests. Indeed, she argues that memories of colonial history in particular are critical in the Southern media [40].

Thus, while we can expect certain continuities in news media across countries in terms of institutions, organizations, and discursive and practical conventions, particularly given the historic Northern dominance and influence in these arenas globally, we can also expect key discontinuities. This is especially the case given memories of colonial rule, particular concerns such as development in the Global South, and the growing influence of Asia. To be clear, we are not implying any stark binaries between North and South. The Global North, for example, certainly includes diasporas from the Global South, and the Indian diaspora is a critical player within the NYT coverage of India (For more on issues of migrant and post-migrant children's knowledge of "some" countries, see [45]) ${ }^{4}$.

4 As Purkayastha writes, the role of diasporas in acting as "native informants" for "home countries" is a fascinating research topic in its own right. For the purposes of this paper, based on the insights of Purkayastha and other immigration scholars, especially those who study post-migrant generations, we wish to insert a cautionary note. 
Nevertheless, we find this distinction between Northern and Southern media in terms of memories and experiences of post/colonial relations useful for explaining key distinctions across these media.

\subsection{Sexual Violence in "Other" Places: The Role of North-South Power Relations in Media Coverage}

Regarding global or international coverage of rape and sexual assault, we can also ask how North-South power relations and consequent geographic inequality in news have shaped such coverage. We contend that the histories of colonialism, imperialism, and neo-colonialism, and their related racialized constructions of the sexualities of black and brown bodies, have provided the lenses through which such coverage has emerged. One early such example is that of the "Indian Mutiny" of 1857 (or alternatively, the First War of Independence), wherein a series of uprisings and rebellions over the colonial territory which were violently quashed, came to be known in the metropole largely via press coverage of the so-called savagery of the indigenous people. Specifically, the British press represented the incident through the frame of the alleged (and unsubstantiated) sexual violence of Indian men toward white British women. In doing so, the media justified the severity of the colonialist response to the uprising and of the "civilizing values" of the colonial project more broadly $[46,47]$. Likewise, scholars have pointed to the colonial origins of US media as well $[48,49]$. Block, for example, shows how newspapers in colonial North America similarly demonized men of color, associating black and Native American men with the crime of rape in particular while framing rape committed by white men as atypical or extraordinary [49].

These early examples are a window onto the history and development of global news as situated within transnational, racialized, and gendered relations of power. We submit that these early moments were also key in providing the narratives or repertoires from which later explanations of sexual violence in post/colonial spaces would draw. For example, such emphasis on the sexual savagery of racialized men has also been evident in more recent media characterizations of particular countries within the Global South from South Africa to the Democratic Republic of Congo to India as the "rape capital of the world" (See for example [50,51]), despite notoriously unreliable and incomparable data across states.

In fact, Geertsema identities several different journalistic stances on the part of western and other journalists toward the foreign and their implications for news about the diverse contexts of women's experiences globally. First, she identifies a nationalist orientation, wherein journalism takes a "clash of civilizations" approach shaped by colonialism and ethnocentrism. Here, "postcolonial women are forced to remain silent partly because of "the Western press's inability to envision such women as speaking subjects on public issues" [52] (p. 153). The above discussion of rape in the "Indian Mutiny" approximates such a stance. Second, she identifies a "cultural globalization" orientation, where journalism is less oriented to the nation and more oriented to the globe. Regarding gender and women, however, this sort of journalism typically takes a problematic "global feminist" stance where women's experiences globally are understood from a western, neo-colonial perspective. While issues such as sexual and other forms of violence may be reported on, there is a dearth of historical context, with

Migrants who have lived away from their countries of origin for a long time, and their children who are molded by the country in which they live their lives, rarely retain or develop in-depth knowledge or understanding of the migrants' country of origin (unless it is their subject of work or study). Thus the use of migrants and their children as native informants creates a type of racialized confirmatory echo chamber for some already constructed news 'realities'. 
stereotypes about "third world" cultures and traditions reproduced. The above discussion of different countries as "rape capitals" of the world may be seen as an example of such a stance. Finally, she identifies a third possibility of a "glocal" journalism where local perspectives and voices are more fully included and the approach toward gender is a more complex transnational feminism that takes into account transnational and other power relations having to do with class, race, nation, culture, sexuality, and so on [52]. Such an approach might consider rape in "other" places in terms of complex local and global histories of colonialisms, postcolonial nationalisms, global capitalism and so on. We find these distinctions useful here for thinking about the kinds of journalistic orientations exhibited by the NYT and the TOI toward the two rape cases we are interested in.

Additionally, while Geertsema's typology points to the transnational dimensions and consequences of histories of racialization, we contend that the intersectional emphasis on the hyper-visibility of men of color as perpetrators and invisibility of women of color as victims within the US is a manifestation of such processes at the level of or within one nation. We suggest, thus, that national media orientations to the trans/national and to the sub/national are but two sides of one nationalist coin and as such, are more fruitfully studied together.

Below, we consider the differing orientations toward both rape cases on the part of the NYT and the TOI, given the colonial, post/colonial and national histories of journalism; the implications of the recent rise of Asia; and the varying orientations to gender and the foreign identified by Geertsema. In particular, we highlight how media portrayals at the sub/national level are intimately interconnected with portrayals at the trans/national level, as both are integral to nationalist constructions of self. Thus, a multi-scalar approach provides a better explanation of racialized, sexualized media practices today.

\section{Data}

The structure of the NYT online paper includes standard sections, such as World, US, Sports, Opinion, etc., with the World further subdivided into regions such as Asia Pacific and Europe. The online paper is also comprised of a number of blogs, including The Learning Network, which is a blog that uses NYT content to create lesson plans for students and fosters discussion amongst students; the Lede, which is a "blog that remixes national and international news stories, adding information gleaned from the Web or gathered through original reporting to supplement articles in The New York Times and provide fresh perspectives on events" (See [53]); India Ink, a blog specifically on news (articles, opinion, interviews, etc.) of India which ran from 2011 through 2014; and IHT Rendevouz, which was a blog "dedicated to analyzing the news for a global audience" (See [54]), retired in June of 2013. The structure of the TOI online paper also has a number of standard sections, including City, India, World, Business, Entertainment, Opinion, and so on, with sections like the World also having further subsections like US, Pakistan, South Asia, UK, China, Middle East and a section called Rest of the world. We looked at online newspaper coverage, including articles, interviews, analysis, editorials and blogs on either case from the date of each event (11 August 2012 for the Steubenville case and 16 December 2012 for the New Delhi case) through 16 March 2013. While we were primarily interested in pieces that were directly concerned with our cases, we included all pieces that at least directly referenced one of the two cases. The total number of pieces we found for each case, in each paper for the period of interest, is indicated in the table below. 


\section{News Media and the Geographies of Rape}

Table 1, below, shows that despite the extended time period allotted for the Steubenville case, this case received far less coverage than did the Delhi case. While the TOI covered Steubenville only once during the time period under question, the NYT also spent only $11 \%$ of its coverage on Steubenville. Furthermore, for the NYT coverage of Steubenville that is evident, this coverage does not begin until 16 December 2012, a full four months after the event (incidentally, it began its coverage of Steubenville at about the same time that it began its coverage of Delhi, though in the case of the former the coverage was quite belated). For the one piece on Steubenville published by the TOI, it emerged even later, on 10 January 2013.

Table 1. Coverage of Each Case in NYT and TOI.

\begin{tabular}{cccccc}
\hline \multicolumn{6}{c}{ Number and Percent of Pieces Published } \\
\hline NYT & $\%$ & TOI & $\%$ & Total for Each Story \\
Delhi & 129 & $45 \%$ & 155 & $55 \%$ & 284 \\
$\%$ & $89 \%$ & & $99 \%$ & & \\
Steubenville & 16 & $94 \%$ & 1 & $6 \%$ & 17 \\
$\%$ & $11 \%$ & & $1 \%$ & & \\
Total for each paper & 145 & & 156 & & \\
\hline
\end{tabular}

Given such unevenness in the coverage of the two cases, we argue that Delhi is very visible across both papers, while Steubenville is significantly less visible. Thinking of these cases as national news, since TOI is an Indian paper it is not surprising to see the number of pieces on the Delhi case. The relative invisibility of Steubenville can, at least on a preliminary basis, be attributed to the same factor - it is not part of India's national news. The large number of articles in the NYT, however, gives it a kind of visibility that cannot be explained on the same terms. Indeed the hyper-visibility of Delhi compared to the relative invisibility of Steubenville leads to the next question. What sort of visibility is provided within the coverage given? To answer this question, we examined the central themes or points of emphasis within the coverage provided. We found some stark contrasts in each paper's coverage of each case. Chart 1 below summarizes key patterns on the Delhi case.

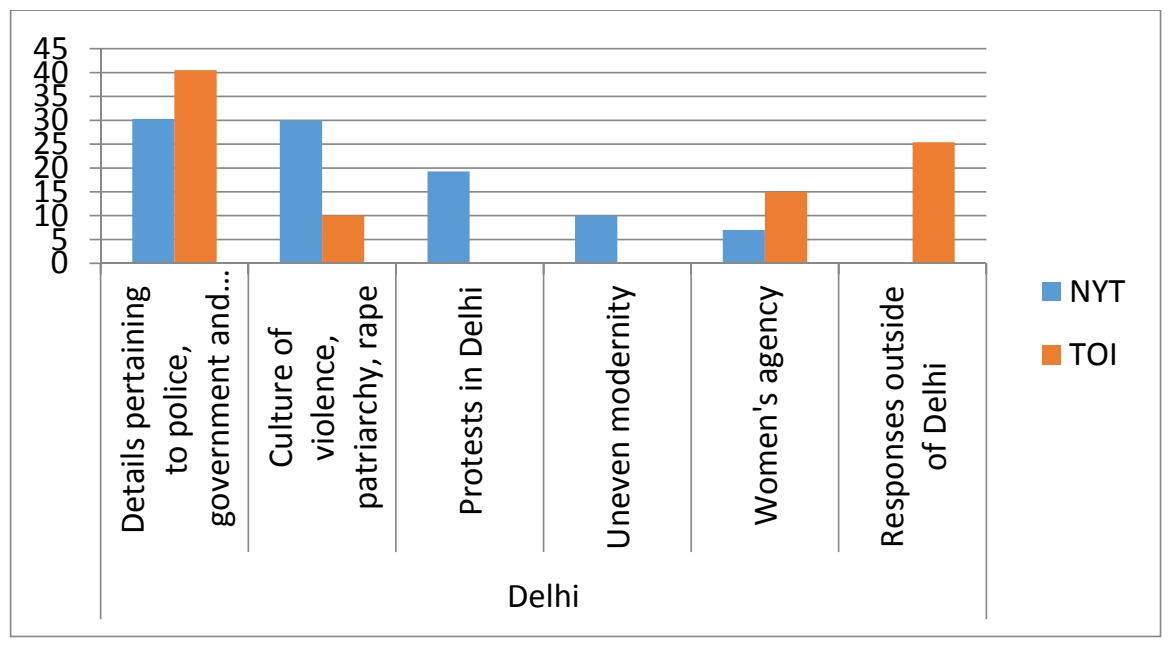

Chart 1. Central Themes on Delhi Case across Both Papers. 
Both papers offered the most pieces on ongoing details in the investigation in terms of specific features and actions of the police, criminal justice and government institutions. Beyond this predominant theme, for the NYT, the central theme that recurs is one of patriarchy and women's oppression within India as a whole: "The brutal gang rape of a young woman in New Delhi this month has cast a cold light on how badly India treats its women" ("Rape in the world's largest democracy," NYT, 28 December). Two discursive tactics help frame this rape case as a larger cultural or societal problem. First, the Delhi rape case is repeatedly referenced in connection with other rape cases in order to point to a larger societal-level rape culture that transcends individual cases. For example, in one piece, a story about a different rape is interrupted in the middle to bring in details on the Delhi case. After these details, discussion of the rape in question ensues ("As Protests Sweep Delhi, Another Gang Rape in Bihar," NYT, 19 December). Second, this rape culture is placed on a continuum of sexual and physical violence Indian women are said to suffer, from sex selection and son preference to acid attacks, dowry death, sexual harassment, child brides, discrimination against the girl child, and inadequate government and police responses to women's issues, all of which together comprise "how badly India treats its women." For example, one author writes "While a horrific gang rape in New Delhi has transfixed India and drawn attention to a violent epidemic, rape is just one facet of a broad range of violence and discrimination that leads to the deaths of almost two million women a year, researchers say. Among the causes are not only sexual violence but also domestic violence, family disputes and female infanticide, as well as infant neglect and poor care of the elderly that affect girls and women far more than boys and men" ("India's new focus on rape shows only the surface of women's perils," NYT, 12 January).

Beyond this societal-level rape culture and patriarchy, a second theme is of anger and protests in Delhi around the particular rape case, which are demanding changes to the culture of patriarchy and violence against women elaborated above. A connected third theme is that of an uneven modernity or an incomplete modernity. Consider, for example, the following statements:

"India basks in its success as a growing business and technological mecca but tolerates shocking abuse of women" ("Rape in the World's Largest Democracy," NYT, 28 December). "Just a tiny sliver of India's population can afford a computer or has access to the Internet, but the young, educated subset of this group has become increasingly galvanized over the New Delhi rape case" ("Six charged with murder in India after rape victim's death," NYT,

29 December).

What emerges in this coverage of the NYT, then, is a discursive framework wherein the protesters represent the modern (and egalitarian) against the patriarchal tradition that sanctions violence against women. Further, the Delhi victim is posited as a symbol of the modern as well. For example, in a piece on her life, the author writes, "The idea of career first and then marriage is a relatively new one in India, where women, even professionally trained ones, often quit their jobs when they wed". ("An ambitious woman from a Delhi neighborhood of migrants", NYT, 9 January). Thus for famed NYT columnist Thomas Freidman, both the protesters and the victim are members of the "virtual middle class" ("The Virtual Middle Class Rises", NYT, 2 February; "Thomas Freidman answers your questions", NYT, 18 February). As members of this virtual middle class, they are the vanguard of a modernity still very much in progress. Examining the construction of the perpetrators as well, 
Roychowdhury points out that in contrast to the construction of the victim as "modern" the perpetrators are associated with "traditional culture"-A binary which elides the significantly overlapping class and caste backgrounds of both [55].

Thus, in the NYT, the predominant juxtaposition of the protestors and the victim on the one hand versus the perpetrators and especially patriarchal rape culture on the other can be seen as a staging of a grand battle between Tradition and Modernity. Uma Narayan [56] discusses the notion of "death by culture" to talk about colonialist constructions of particular cultures as especially prone to violence against women. We argue that the coverage of the NYT advances an explanation of "rape by culture" to suggest that the primary culprit in the Delhi rape case is Indian culture. If Indian rape culture is the antagonist, the protagonist is the victim and the protesters, who represent modernity and associated notions of women's rights. We examined whether the discourse of the NYT was differentiated by whether authors were of Indian descent or not. Echoing the point made in endnote viii, we found that this distinction did not make much of a difference in terms of the deployment of notions of Indian rape culture and insufficient modernity.

In clear contrast to this coverage, the most prominent emphasis for the TOI Delhi coverage after the coverage of police, government and criminal justice is that of agency at a variety of levels, first in terms of collective responses to the gang rape around the country and second in terms of individual women's agency. On the first of these, the paper spent significantly more space on protests and responses to the Delhi case not just in Delhi but in cities and (relatively smaller) towns across the country including in large and small urban areas, such as Guwahati, Shillong, Silchar, Dhanbad, Chandigarh, Patiala, Ghaziabad, Kolkata, Mumbai, and Thiruvananthapuram. It detailed group efforts by political party affiliated groups, groups not affiliated with political parties, students, workers, homemakers, and celebrities. It listed activities such as protest marches and art projects, as well as new civil society and government projects at multiple levels having to do with education, policy and infrastructure. Second, the paper elaborated individual actions taken by women, such as enrolling in self-defense classes, as well as carrying pepper spray, chili powder, knives, and guns. While the paper did discuss a culture of violence and rape, the discussion of patriarchy and women's oppression in the TOI is not framed discursively in terms of a dichotomy of tradition versus modernity as it is in the NYT. Rather, while patriarchy is acknowledged as a larger long term issue that must be dealt with, the focus of the TOI is on what can and is being done in the wake of the Delhi rape. Perhaps this distinction between the coverage of the NYT and the TOI is best illustrated by the fact that while the NYT published over 100 pieces on the themes listed above, just three days after the Delhi rape incident, the TOI published a piece entitled "Enough talk, let's make women safe" (TOI, 19 December).

Regarding the Steubenville case, the NYT coverage of Steubenville is quite instructive in its contrasts to the NYT coverage of Delhi. In the 16 pieces published, there is no overarching discussion of a culture of violence or of tradition versus modernity. The predominant theme, rather, is the noteworthy social media/online dimension of the story wherein portions of the assault had been reported by witnesses via photos, videos and on Twitter and Instagram, and the case was politicized online before there was a significant police response (for an academic treatment of this online/social media dimension, see [57]). A second dominant theme was that of a problematic football rape culture which sought to excuse heroic sports players and blame victims. Notably, unlike the nationalized 
discussion of culture in the Delhi case as pertaining to Indian cultural and national tradition, the discussion of culture for the Steubenville case was localized to football culture within the town of Steubenville: "residents argue that adulation for the football team, one of the few jewels left in a city eroded by economic decline, has fostered a culture that allowed such a thing to occur" ("Case already tried in social media heads to court", NYT, 12 March). ${ }^{5}$ In this fashion, a rape in the city of New Delhi was "scaled up" to the Indian nation as a whole and connected as it was to cultural tradition, was also projected back in time. A rape in the town of Steubenville, on the other hand, was "scaled down" to a particular town's football culture and associated as it was with exigencies of the moment, was removed from any meaningful historical context.

This discursive nationalization of Delhi as a problem of Indian rape culture and localization of Steubenville to a particular town's football culture was further reinforced in terms of where the paper placed both sets of stories. That is, the NYT published the Steubenville story as a "sports" story in its Sports section until 12 March, when it was moved to the US section of the paper. In contrast, Delhi was mainly covered in the India Ink blog, as well as in the Asia Pacific section. From the beginning, then, while Steubenville was framed as less about the US and more about an incident involving a particular set of actors in a specific locale; Delhi was framed as about Asia and particularly India, ${ }^{6}$ as one among a long history of inequities.

On the one piece on the Steubenville case published by the TOI, the framing of the case is quite instructive on the distinctive politics of the TOI. The title of the piece is "The US has its own Nirbhaya"-Nirbhaya being the nickname given to the victim of the Delhi rape and translating as "fearless" in English. The piece is an interview with the blogger who first brought the case to the public's attention. The piece begins, “As India grapples with the gang-rape and death of the 23-year-old student in Delhi, the US is coming to terms with an equally disturbing case on its own soil (TOI, "The US has its own Nirbhaya")". In the framing of the TOI, then, there is no hierarchicalization between the US and India in terms of these two cases and their associated rape cultures, as they are understood as "equally disturbing".

\section{Intersectionalities in a Transnational Frame}

Contra the assumption that women of color victims of rape are more invisible compared to white women in news media, then, the above patterns demonstrate quite the opposite. Some of this uneven coverage of Delhi versus Steubenville may be explained by the fact that the former comes closer to the problematic "real rape" image that underlies news media depictions. However, the rape myths elaborated above which dichotomize assaults into "real" versus "not real" rape cannot explain the

5 In a separate examination, we also looked at the local coverage of the Steubenville case in the Pittsburg Gazette. Here the news focused primarily on the incidents and the sentencing. Except for two articles on the outrage against CNN which appeared to sympathize with the rapists, there was no coverage of any protests or commentaries about local cultures.

6 The framing is particularly interesting because our search through the academic literature - 62 social science articles which included the word sexual violence — published in 2012 or 2013 shows that a significant numbers of authors were writing about the college rape culture in the US. In other words if the journalists sought to reach out to experts in the field, college rape cultures in the US would inevitably have been a theme they encountered. 
framing of the Delhi case in terms of Tradition versus Modernity-Neither can intersectional elaborations of early feminist work on rape myths. Indeed, in order to understand the peculiar treatment of the Delhi rape in the NYT, we need to turn to transnational histories of racialization. In particular, we need to examine larger histories of colonialism, imperialism and neocolonialism which have produced a civilizational narrative in which states in the Global North are always and inevitably further along on the scale of progress regarding democracy, freedom, and gender and sexual equality compared to states in the Global South $[14,16,19,58]$. The dichotomy of Tradition versus Modernity conveniently captures this differential location on the scale of progress. Finding a similar discourse in her examination of the treatment of the Delhi case in some other US media, Durham argues that the "mediated deployment of space and place" are "potent signifiers of gender and sexuality" [59]. From within this discursive framework then, understanding the Delhi rape requires an elision of cases such as Steubenville, whose very existence in the site of progress and modernity "at home" threatens civilizational assumptions about us as opposed to them.

Relatedly, the sociology of news literature argues that domestic news tends to be prioritized over foreign news. We argue that this is not always the case and that the kind of story matters. Specifically in the case of sexual violence against women in states that identify with the civilizational narrative above, the nationalist underpinnings of national news dictate that whatever the problem is regarding women and gender here, it is not as bad as it is "over there", thereby requiring more attention be paid to the foreign over the domestic for this particular type of crime. A good example of this is an article titled Is Delhi so different from Steubenville? by Nicolas Kristof (13 January 2013) which acknowledges "some" similarities in terms of the Steubenville and Delhi cases, but concludes that the US has made very significant progress in reducing violence against women and that for India and other countries and that " $(\mathrm{T})$ he United States could help change the way the world confronts these issues," thus rendering invisible the efforts underway in India, over decades, to address sexual violence (For even a brief historical overview of such efforts, see [60]). Contra some basic assumptions of intersectional and sociological approaches to news, then, racialized victims and the foreign can both be foregrounded for the sake of (re)securing colonialist civilizational and nationalist objectives. In fact, combining the insights of the transnational literature on the media imageries that create and sustain gendered racial hierarchies across nation-states, and the nation-focused literature on the invisibility of women of color in the US, we would argue that in an increasingly global world, both elements are important for upholding the supremacy of a racial nation-state. Thus the Delhi case serves as a marker of disorder over there, while the invisibilization of non-white women's rape contributes to the myth of how well things are over here.

In contrast to the NYT, the TOI does prioritize domestic over foreign news, which helps explain its lack of coverage of the Steubenville case. As some have suggested, however, news media in the Global South have quite distinct concerns shaped by memories and experiences of anticolonial and postcolonial struggle $[40,43]$. Such a perspective of postcolonial nationalism-However refracted through neoliberal, global capitalist, and related prisms-May help to explain not only the TOI's unwillingness to engage in an extended discussion of cultural sources of sexual violence against women but also its determined focus on agency and change.

Reflecting further on the hypervisibility of the Delhi case, beyond these post/colonial histories and identities, can we not say that the Delhi story is simply more newsworthy, or simply more sensational, 
or simply more likely to sell within the marketplace, especially in the US? After all, the Delhi case was much more physically violent and the victim in that case did lose her life, while the one in Steubenville survived. We argue that this is too simple. After all, sensationalistic stories of rape routinely emerge for other post/colonial spaces as well, yet they do not receive the kind of extended coverage the Delhi story has received. Rather, we argue that the Delhi story has become more "newsworthy", more sensational and more likely to sell in light of recent political economic and cultural shifts which themselves gain their significance in the context of larger colonial histories. Firstly, the increased coverage of the NYT and a number of other Northern media outlets regarding China and India has emerged in the wake of the economic rise of China and India as well as a US Indian diaspora that is now perceived to be the most economically successful minority in the country $[61,62] .{ }^{7}$ Regarding India, the bulk of NYT coverage of India occurred via its India-specific blog, India Ink, which was the first country-specific blog the newspaper ever created (and which lasted from 2011-2014). In this new and specific attention to India, the NYT was joined by other publications such as The Wall Street Journal, The New York Daily News, and The Huffington Post (some of these have since shut down [63]). This increased news coverage has been accompanied by an increased visibility in popular culture, from transnational Bollywood to US films and television shows [64,65]. It is within this context of heightened visibility, perceived economic success of Indians within the US and the rise of Asia that the Delhi case becomes newsworthy, sensational and sellable within the Global North. Even more, we suggest that such dynamics have brought to the fore deep anxieties about Asian emergence and Northern and particularly US decline. The rise of Asia and the perceived success of the diaspora present challenges to the long-held civilizational narrative and its assumptions about cultural-racial superiority, progress and so on. From this perspective, cases such as the Delhi case and its truth about "how badly India treats its women" provide some reassurance and solace about the ongoing significance of older civilizational hierarchies and who belongs where.

\section{Conclusions}

We argue that the NYT and the TOI have significantly different orientations to the rape cases examined here, due to the colonial, post/colonial and nationalist histories of journalism as well as the recent rise of Asia. For the NYT on the Delhi case, older civilizational discourses of the excessive and aberrant sexuality of brown bodies, barbarism and static tradition combine with newer discourses of economic modernization in the new India to construct a framework of an incomplete modernity where some within the nation represent modernity while others represent tradition. A problematic global feminist discourse further reproduces this binary of tradition and modernity in the name of feminism and women's rights. While such a nationalist construction of the US as a site of progress, freedom and so on requires an elision of the racialized power structures which enable and perpetuate the rape of victims of color within the US (and an overemphasis on white victims), this same nationalist construction of the US also requires an elision of white victims in relation to racialized, Orientalized victims abroad. Such an elision renders instances of gender and sexual violence in the Global North out of place and out of time-insignificant, unremarkable, and so forgettable exceptions to the rule.

7 Of course, the focus on Asian Indians as the most economically successful minority is problematic in that such a construction erases the considerable diversity within the group. 
This relative invisibility of violence against women of color in the US and the hypervisibility of women elsewhere perpetuates the civilizational narrative and its profound implications for collective memory regarding sexual assault, space and race.

Significantly, while global power relations propel the NYT's presumed entitlement to speak on a case half way around the world, these same power relations inhibit any such inclination on the part of the TOI. That is the TOI, situated within an uneven North-South tapestry of power, has no space to make a similar transnational civilizational superiority claim on behalf of India. Thus, the TOI's postcolonial nationalism focuses largely on the Delhi case and emphasizes women's agency and social change, with its scant Steubenville coverage stressing similarities between India and the US. As such, the TOI provides a powerful local, perhaps "postcolonial feminist" counterpoint to the global feminism produced by the NYT.

In the case of both papers, then, their differential locations within global power relations produce particular kinds of nationalisms, particular kinds of feminisms, as well as particular kinds of orientations to both the sub/national and the trans/national. Relatedly, their differential locations also produce particular kinds of visibilities and invisibilities which themselves shift depending on the scale of analysis. Ultimately, then, there is an urgent need to expand our frameworks beyond the nation and even more, to pay attention to multiple scales of analysis simultaneously. Following Chowdhury, contesting global feminism's disappearance of the concerns of US women of color requires a "braiding together" of US women of color and transnational feminist frameworks [20]. At stake is the potential and possibility for a collective praxis of a "feminism without borders [59]".

\section{Acknowledgments}

This research has not received any funding.

\section{Author Contributions}

Both authors conceived of the idea, collected the data, conducted the analysis, and wrote the paper together.

\section{Conflicts of Interest}

The authors declare no conflict of interest.

\section{References}

1. Crenshaw, K.W. Demarginalizing the intersection of race and gender: A black feminist critique of antidiscrimination doctrine, feminist theory and antiracist politics. Univ. Chicago Legal Forum 1989, 140, 139-167.

2. Crenshaw, K.W. Mapping the margins: Intersectionality, identity politics, and violence against women of color. Stanford Law Rev. 1991, 43, 1241-1299.

3. 4 International Media \& Newspapers. Top 200 newspapers in the world. Available online: www.4imn.com/top200/ (accessed on 10 November 2014). 
4. MondoTimes. The highest circulation newspapers in the world. Available online: www.mondotimes.com/newspapers/worldtop100.html (accessed on 10 November 2014).

5. ReadingTree. Top 10 most read newspapers in the world. Available online: www.clicktop10.com/2013/07/top-10-most-read-newspapers-in-the-world/ (accessed on 10 November 2014).

6. Tuchman, G. Making News: A Study in the Construction of Reality; Free Press: London, UK, 1978.

7. Schudson, M. The Sociology of News, 2nd ed.; W.W. Northon \& Company: New York, NY, USA, 2011.

8. Burt, M. Rape myths. In Confronting Rape and Sexual Assault; Odem, M.E., Clay-Warner, J., Eds.; Rowman and Littlefield: Lanham, MD, USA, 1998; p. 129.

9. Wilson, C.C., II; Gutierrez, F.; Chao, L.M. Racism, Sexism and the Media; SAGE: Thousand Oaks, CA, USA, 2003.

10. Los, M.; Chamard, S.E. Selling newspapers or educating the public? Sexual violence in the media. Can. J. Criminol. 1997, 39, 293-328.

11. Ardovini-Brooker, J.; Caringella-Macdonald, S. Media attributions of blame and sympathy in ten rape cases. Crim. Justice Stud. 2002, 15, 3-18.

12. Grewal, I.; Kaplan, C. Scattered Hegemonies: Postmodernity and Transnational Feminist Practice; University of Minnesota Press: Minneapolis, MN, USA, 1994.

13. Grewal, I.; Kaplan, C. Global identities: Theorizing transnational studies of sexuality. GLQ: J. Lesbian Gay Stud. 2001, 7, 663-679.

14. Kamalipour, Y. The U.S. Media and the Middle East: Image and Perception; Greenwood Press: Westport, CT, USA, 1995.

15. Karim, K.H. Islamic Peril: Media and Global Violence; Black Rose Books: Montreal, QC, Canada, 2000.

16. Klein, C. Cold War Orientalism: Asia in the Middlebrow Imagination, 1945-1961; University of California Press: Berkeley, CA, USA, 2003.

17. Mama, A. Sheroes and villains: Conceptualizing colonial and contemporary violence against women in Africa. In Feminist Genealogies, Colonial Legacies, Democratic Futures; Alexander, M.J., Mohanty, C.T., Eds.; Routledge: New York, NY, USA, 1997; pp. 46-62.

18. Street, L. Veils and Daggers: A Century of National Geographic's Representation of the Arab World; Temple University Press: Philadelphia, PA, USA, 2000.

19. Wilkins, K.G. Middle eastern women in western eyes: A study of us press photographs of middle eastern women. In The U.S. Media and the Middle East: Image and Perception; Kamalipour, Y., Ed.; Greenwood Press: Westport, CT, USA, 1995; pp. 50-61.

20. Chowdhury, E.H. Locating global feminisms elsewhere: Braiding us women of color and transnational feminisms. Cult. Dynam. 2009, 21, 51-78.

21. Coogan-Gehr, K. The politics of race in U.S. Feminist scholarship: An archaelogy. Signs 2011, 37, 83-107.

22. Patil, V. From patriarchy to intersectionality: A transnational feminist assessment of how far we've really come. Signs 2013, 38, 847-867. 
23. Falcon, S.M.; Nash, J. Shifting analytics and linking theories: A conversation about the "meaning-making" of intersectionality and transnational feminism. Wom. Stud. Int. Forum 2015, $50,1-10$.

24. MacKenzie, G.; Marcel, M. Media coverage of the murder of U.S. Transwomen of color. In Local Violence, Global Media; Cuklanz, L.M., Moorti, S., Eds.; Peter Lang: New York, NY, USA, 2009; pp. 79-106.

25. Jackson, S.J. Framing Megan Williams: Intersecting discourses of race, class, and gender in television news coverage of racialized rape. Fem. Media Stud. 2013, 13, 46-63.

26. Cuklanz, L.M. News coverage of ethnic and gender issues in the big dan's rape case. In Feminism, Multiculturalism and the Media: Global Diversities; Valdivia, A.N., Ed.; SAGE: London, UK, 1995; pp. 145-162.

27. Cacho, L. Social Death: Racialized Rightlessness and the Criminalization of the Unprotected; New York University Press: New York, NY, USA, 2012.

28. Moorti, S. Color of Rape: Gender and Race in Television's Public Spheres; State University of New York Press: Albany, NY, USA, 2002.

29. Smith, V. Not Just Race, Not Just Gender: Black Feminist Readings; Routledge: New York, NY, USA, 1998.

30. Stabile, C. White Victims, Black Villain; Routledge: New York, NY, USA, 2006.

31. Cuklanz, L.M.; Moorti, S. Local Violence, Global Media; Peter Lang: New York, NY, USA, 2009.

32. Minhas, S.F. The politics of rape and honor in Pakistan. In Local Violence, Global Media: Feminist Analyses of Gendered Representations; Cuklanz, L., Moorti, S., Eds.; Peter Lang: New York, NY, USA, 2009; pp. 65-78.

33. Angst, L.I. The sacrifice of a schoolgirl: The 1995 rape case, discourses of power, and women's lives in Okinawa. In Local Violence, Global Media: Feminist Analyses of Gendered Representations; Cuklanz, L., Moorti, S., Eds.; Peter Lang: New York, NY, USA, 2009; pp. 132-159.

34. Scully, P. Media constructions of ethnicized masculinity in South Africa. In Local Violence, Global Media: Feminist Analyses of Gendered Representations; Cuklanz, L., Moorti, S., Eds.; Peter Lang: New York, NY, USA, 2009; pp. 160-180.

35. Chalaby, J. The Invention of Journalism; Palgrave Macmillan: New York, NY, USA, 1998.

36. Schudson, M.; Waisbord, S. Toward a political sociology of the news media. In Handbook of Political Sociolgy: States, Civil Societies and Globalization; Hicks, A.M., Janoski, T., Schwartz, M., Eds.; Cambridge University Press: Cambridge, UK, 2011.

37. Machin, D. Global Media Discourse: A Critical Introduction; Routledge: New York, NY, USA, 2007.

38. Silverstone, R. Media and Morality: On the Rise of hte Mediapolis; Polity Press: Malden, MA, USA, 2007.

39. Gans, H. Deciding What's News: A Study of CBS Evening News, NBC Nightly News, Newsweek and Time; Vintage Books: New York, NY, USA, 1979.

40. Mody, B. The Geopolitics of Representation in Foreign News; Lexington Books: Lanham, MD, USA, 2010.

41. Ginneken, J.V. Understanding Global News; SAGE: London, UK, 1998. 
42. Thussu, D.K. Why internationalize media studies and how? In Internationalizing Media Studies; Thussu, D.K., Ed.; Routledge: New York, NY, USA, 2009; pp. 13-31.

43. Haque, S.M.M. What Is News in India? A Content Analysis of the Elite Press; University Press of America: New York, NY, USA, 1988.

44. Malhan, S.P.M. The Toi Story: How a Newspaper Changed the Rules of the Game; Harper Collins Publishers India: Uttar Pradesh, IN, USA, 2013.

45. Purkayastha, B. Negotiating Ethnicity: Second-Generation South Asian Americans Traverse a Transnational World; Rutgers University Press: New Brunswick, NJ, USA, 2005.

46. Woollacott, A. Gender and Empire; Palgrave Macmillan: Hampshire, UK, 2006.

47. Streets, H. The rebellion of 1857: Origins, consequences and themes. Teach. South Asia: Int. J. Pedag. 2001, 1, 85-104.

48. Bailey, F.Y. Rape, race and the media. In Race, Crime and the Media; Bing, R.L., Ed.; McGraw Hill: New York, NY, USA, 2009; pp. 10-27.

49. Block, S. Rape and race in colonial newspapers, 1728-1776. Journal. Hist. 2001, 27, 146-156.

50. Mapenzauswa, S. Outcry over India gang rape shames some in South Africa. Available online: http://www.reuters.com/article/2013/02/06/us-safrica-rape-idUSBRE9150RB20130206 (accessed on 10 November 2014).

51. Schuler, C. One woman's crusade against rape in South Africa. Available online: http://www.csmonitor.com/2000/0412/p1s4.html (accessed on 10 November 2014).

52. Geertsema, M. Women and news: Making connections between the global and the local. Fem. Media Stud. 2009, 9, 149-172.

53. New York Times. The Lede: The New York Times Blog. Available online: http://thelede.blogs.nytimes.com/about-the-lede (accessed on 10 November 2014).

54. New York Times. Iht rendevouz. Available online: http://rendezvous.blogs.nytimes.com/2013/ 06/28/au-revoir-rendezvous/ (accessed on 10 November 2014).

55. Roychowdhury, P. The Delhi gang rape: The making of international causes. Fem. Stud. 2013, 39, 282-292.

56. Narayan, U. Dislocating Cultures: Identities, Traditions and Third-World Feminism; Routledge: New York, NY, USA, 1997.

57. Armstrong, C.L.; Hull, K.; Saunders, L. Victimized on plain sites: Social and alternative media's impact on the steubenville rape case. Dig. Journal. 2015, doi:10.1080/21670811.2015.1040043.

58. Patil, V. Negotiating Decolonization in the United Nations: Politics of Space, Identity and International Community; Routledge: New York, NY, USA, 2008.

59. Durham, M.G. The scene of the crime: News discourse of rape in India and the geopolitics of sexual assault. Fem. Media Stud. 2014, 15, 175-191.

60. Kumar, R. The History of Doing: An Illustrated Account of Movements for Women's Rights and Feminism in India, 1800-1990; Zuban: New Delhi, India, 1990.

61. Gjelten, T. The world in 2030: Asia rises, the west declines. Available online: http://www.npr.org/2012/12/10/166895624/the-world-in-2030-asia-rises-the-west-declines (accessed on 10 November 2014). 
62. Sohrabji, S. Indian Americans most educated, richest, says pew report. Available online: http://newamericamedia.org/2012/07/indian-americans-most-educated-richest-says-pew-report.php (accessed on 10 November 2014).

63. IANS. New York Times Drops India Ink. Available online: http://www.politicsballa.com /2014/07/154360/new-york-times-drops-india-ink\#220fQ0147X4dgYEc.99 (accessed on 10 November 2014).

64. Dave, S. Indian Accents: Brown Voice and Racial Performance in American Television and Film; University of Illinois Press: Urbana, IL, USA, 2013.

65. Jacobs, T. Hollywood Goes South Asian. Available online: http://www.salon.com/2012/08/30/ hollywoods_new_fascination_with_south_asians/(accessed on 10 November 2014).

(C) 2015 by the authors; licensee MDPI, Basel, Switzerland. This article is an open access article distributed under the terms and conditions of the Creative Commons Attribution license (http://creativecommons.org/licenses/by/4.0/). 